J. Clin. Chem. Clin. Biochem.

Vol. 24, 1986, pp. $441-444$

(C) 1986 Walter de Gruyter \& Co. Berlin - New York

\title{
Plasma Fibronectin Depletion After Cardiac Surgery in Children With or Without Cardiopulmonary Bypass
}

\author{
By F. Labrousse
}

Department of Clinical Chemistry, Hôpital Laennec, Paris

\section{A. Dequirot}

Intensive Care Unit of Cardiovascular Surgery, Hôpital Laennec, Paris

P. Sos and N.T. Le Quang

Department of Clinical Chemistry, Hôpital Laennec, Paris

(Received July 29, 1985/February 10, 1986)

Summary: Plasma fibronectin depletion decreases resistance to sepsis. After cardiac surgery, septic complications occur more frequently when the surgical procedure is managed with a cardio-pulmonary bypass than when it is not. To determine whether cardio-pulmonary bypass produces a greater decrease in plasma fibronectin than surgery without cardio-pulmonary bypass, we studied plasma fibronectin concentrations in two groups of children operrated for congenital heart diseases.

Group I: 10 children undergoing surgery with cardio-pulmonary bypass.

Group II: 11 children undergoing surgery without cardio-pulmonary bypass.

Plasma fibronectin was monitored pre-operatively (t 1$)$ and post-operatively at the 6th hour ( $(\mathrm{t} 2), 1$ st $(\mathrm{t} 3)$ and 7 th ( $(\mathrm{t} 4)$ days. In both groups, plasma fibronectin concentration dropped at $(t 2)$ and $(\mathrm{t} 3)$ and rose again at ( $t$ 4). There was no significant difference in plasma fibronectin levels between the two groups at any time. We conclude that the plasma fibronectin decline alone cannot explain why septic complications after surgery are more frequent with cardio-pulmonary bypass than without.

\section{Verarmung des Plasmas an Fibronectin bei Kindern nach Herzchirurgie mit oder ohne kardiopulmonalen Bypass}

Zusammenfassung: Die Verarmung des Plasmas an Fibronectin vermindert die Widerstandskraft gegen Sepsis. Nach chirurgischen Eingriffen am Herzen treten septische Komplikationen häufiger auf, wenn der Eingriff mit einem kardiopulmonalen Bypass durchgeführt wird. Wir untersuchten die Konzentration von Fibronectin im Plasma bei zwei Gruppen von Kindern, die wegen angeborener Herzfehler operiert wurden, um festzustellen, ob der kardiopulmonale Bypass einen bedeutenderen Abfall des Fibronectins im Plasma verursacht als die Chirurgie ohne Bypass:

Gruppe I: 10 Kinder, die sich einer Operation mit dem kardiopulmonalen Bypass unterzogen;

Gruppe II: 11 Kinder, die sich einer Operation ohne kardiopulmonalen Bypass unterzogen.

Fibronectin im Plasma wurde vor der Operation (t 1) und 6 Stunden $(t)$, sowie am 1. (t 3) und 7. Tag (t 4) danach bestimmt. In beiden Gruppen fiel die Fibronectinkonzentration bei (t 2) und (t 3$)$ und stieg bei ( $t$ 4) wieder an. Es bestand zu keiner Zeit ein signifikanter Unterschied zwischen den Fibronectinkonzentrationen im Plasma beider Gruppen. Wir schließen daraus, daß der Abfall der Fibronectinwerte im Plasma allein nicht erklären kann, warum septische Komplikationen nach chirurgischen Eingriffen mit kardiopulmonalem Bypass häufiger sind als ohne. 


\section{Introduction}

Fibronectin is a 440,000 dalton glycoprotein, whose average plasma concentration is $300 \pm 100 \mathrm{mg} \mathrm{l}^{-1}$ (1). One of its functions is to stimulate the reticuloendothelial system (RES) thus contributing to the host's non-immune defences. It also enhances phagocytosis by peripheral blood monocytes of opsonised particles (2). Moreover, plasma fibronectin modulates RES clearance of non bacterial particles and of some bacterial species $(3,4)$. Current opinion indexes the RES defence potential to the serum immunoreactive fibronectin concentration (5) and plasma fibronectin deficiency could increase susceptibility to infection by microbial pathogens (6).

Although cardiac surgery is usually aseptic, some infectious complications are observed, especially when the operation necessitates cardiopulmonary bypass. Several hypotheses have been evoked to explain the higher incidence of infection after cardio-pulmonary bypass: median sternotomy incision (9), impairment of immune system components (10), functional defect of phagocytic cells, notably polymorphonuclear neutrophils (11).

This work aims to determine whether cardio-pulmonary bypass cardiac surgery induces a significant depletion in the plasma fibronectin concentration as compared to cardiac surgery without cardio-pulmonary bypass. Such a depletion could be a factor in the subsequent higher incidence of infection after cardio-pulmonary bypass cardiac surgery.

\section{Patients and Methods}

This study comprises 21 observations on operated children, who had undergone surgery for congenital heart diseases without infectious complications. They were divided into 2 groups:

Group $I$ included 10 children aged 9 months to 13 years (m $\pm \mathrm{SD} ; 82 \pm 45$ months) having : 4 ndergone surgery with cardio-pulmonary bypass. Table 1 summarizes principal clinical data.

Cardio-pulmonary bypass utilized a membrane oxygenator (Rhone-Poulenc*). Priming was realized with aliquots of crystaloid and blood restored from red blood cells and fresh frozen plasma. The average volume was $62 \pm 15.9 \mathrm{ml} \mathrm{kg}^{-1}$.

Initial heparinization (IH) was 250 units $\mathrm{kg}^{-1}$ prolongated by constant intravenous injection of $1 / 4 \mathrm{IH} \mathrm{h}^{-1}$. At the end of cardio-pulmonary bypass, heparin was neutralized by injection of $3.25 \mathrm{mg} \mathrm{kg}^{-1}$ of protamine sulphate.

Per operative blood compensation ranged from 26.6 to $84.2 \mathrm{ml}$ $\mathrm{kg}^{-1}(\overline{\mathrm{x}}=60.8 \pm 20)$. Post operative transfusion ranged from 0 to $25.7 \mathrm{ml} \mathrm{kg}^{-1}(\overline{\mathrm{x}}=7.1 \pm 7.5)$ depending on haemorrhage and/or loading requirements.

Group II included 11 children aged from 2 to 9 years old ( $\mathrm{m}=$ $60 \pm 28$ months) operated without cardio-pulmonary bypass (table 2 summarizes principal clinical data).

Per operative blood compensation varied from 0 to $24 \mathrm{ml} \mathrm{kg}^{-1}$ $(\overline{\mathrm{x}}=3.44 \pm 7.4)$. Post operative compensation varied from 0 to $5 \mathrm{ml} \mathrm{kg}^{-1}(\overline{\mathrm{x}}=2.6 \pm 3.3)$.

Anaesthesia had a mean duration of $297 \pm 53$ min for group I and $178 \pm 51 \mathrm{~min}$ for group II.

Blood samples $(2 \mathrm{ml})$ for plasma fibronectin determination were drawn in glass tubes containing $0.2 \mathrm{ml}$ of $38 \mathrm{~g}^{-1}$ sodium citrate, either via venous catheter during the post operative period or via venous puncture at the time of routine pre and post operative laboratory tests. Four samples were collected for each child: the day before intervention ( $t 1)$, at the 6 th post operative hour ( $t 2)$, the 1 st post operative day $(t 3)$ and the 7 th post operative day ( $t 4)$. After centrifugation $(1500 \mathrm{~g}, 20$ minutes, $4^{\circ} \mathrm{C}$ ) plasma samples ${ }^{\circ}$ were immediately frożen and stored at $-30^{\circ} \mathrm{C}$ until the moment of assay.

Tab. 1. Group I: principal clinical data.

\begin{tabular}{|c|c|c|c|c|c|c|}
\hline \multirow[t]{3}{*}{$\mathrm{N}^{\circ}$} & \multirow{3}{*}{$\begin{array}{l}\text { Age } \\
\text { (months) }\end{array}$} & \multirow{3}{*}{$\begin{array}{l}\text { Duration of } \\
\text { anaesthesia } \\
\text { (min) }\end{array}$} & \multirow{3}{*}{$\begin{array}{l}\text { Cardio- } \\
\text { pulmonary } \\
\text { bypass } \\
\text { duration } \\
\text { (min) }\end{array}$} & \multirow{3}{*}{$\begin{array}{l}\text { Cardio- } \\
\text { pulmonary } \\
\text { bypass } \\
\text { priming } \\
\left(\mathrm{ml} \mathrm{kg}^{-1}\right)\end{array}$} & \multicolumn{2}{|c|}{ Blood compensation*) } \\
\hline & & & & & $\begin{array}{l}\text { per- } \\
\text { operative }\end{array}$ & $\begin{array}{l}\text { post- } \\
\text { operative }\end{array}$ \\
\hline & & & & & $(\mathrm{ml} \mathrm{kg}-1)$ & $\left(\mathrm{ml} \mathrm{kg}^{-1}\right)$ \\
\hline 1 & 120 & 300 & 82 & 57.9 & 84.2 & 0 \\
\hline 2 & 97 & 260 & 100 & 56 & 31.7 & 4.9 \\
\hline 3 & 153 & 220 & 33 & 40.6 & 26.6 & 3.3 \\
\hline 4 & 47 & 270 & 100 & 72.8 & 70.2 & 8.8 \\
\hline 5 & 21 & 340 & 130 & 87 & 65.2 & 13 \\
\hline 6 & 73 & 340 & 188 & 67 & 55.3 & 0 \\
\hline 7 & 77 & 400 & 213 & 58.5 & 84.2 & 25.7 \\
\hline 8 & 36 & 240 & 93 & 83.8 & 68.5 & 18 \\
\hline 9 & 140 & 270 & 125 & 40.1 & 46.4 & 3.2 \\
\hline 10 & 52 & 300 & 51 & 56.8 & 75.8 & 0 \\
\hline
\end{tabular}

*) per-operative: Transfusion of blood products (red blood cells, fresh frozen plasma, whole blood) during intervention and stay in operating room. post-operative: Transfusion of blood products during the first post-operative 12 hours in Intensive Cdre Unit. 
Plasma fibronectin was measured by radial immunodiffusion as described by Mancini (12). Twenty microliters of half diluted plasma were deposited into a well cut in a gel plate containing anti-human plasma fibronectin antibody (L.C. Partigen, Hoechst-Behring*). The amount of deposited fibronectin was determined by measuring the precipitating ring surface. Four dilutions of a standardized plasma containing a known amount of plasma fibronectin were used for calibration, the intra-assay variation coefficients lying between $3 \%$ and $4 \%$.

The data were analysed statistically using analysis of covariance and descriptive sample statistics: Student's t-test or Mann-Whitney's non parametric test for intergroup comparison; paired " $t$ " test or paired Wilcoxon's non parametric test for intragroup comparison; results were expressed in mean \pm standard deviation $(\bar{x} \pm S D)$. Correlation between 2 variables was researched using the least square method. Significance was defined as $\mathrm{p}<0.05$.

\section{Results}

Group I

Initial plasma fibronectin mean levels $(383 \pm 59$ $\mathrm{mg}^{-1}$ ) declined to $314 \pm 52 \mathrm{mg}^{-1}$ at the 6th hour and further to $270 \pm 26 \mathrm{mg} \mathrm{l}^{-1}$ the day after the operation, then rose to $330 \pm 36 \mathrm{mg} \mathrm{l}^{-1}$ on the 7th day. Statistical analysis demonstrated that tiwl subgroups $(1,2,3,4)$ were mutually different (fig. 1).

\section{Group II}

Pre operative plasma fibronectin mean level also declined from $344 \pm 71 \mathrm{mg} \mathrm{l}^{-1}$ to $309 \pm 75 \mathrm{mg} \mathrm{l}^{-1}$ at the 6 th post operative hour and to $234 \pm 76 \mathrm{mg} \mathrm{l}^{-1}$ on the 1st post operative day, then rose to $362 \pm$ $77 \mathrm{mg}$ on the 7th post operative day. Results of the statistical analyses are given on figure 1.

There was no significant difference in the temporal evolution of plasma fibronectin between group I and group II.

Tab. 2. Group III: principal clinical data.

\begin{tabular}{|c|c|c|c|c|}
\hline \multirow[t]{2}{*}{$\mathbf{N}^{\circ}$} & \multirow{2}{*}{$\begin{array}{l}\text { Age } \\
\text { (months) }\end{array}$} & \multirow{2}{*}{$\begin{array}{l}\text { Duration } \\
\text { of } \\
\text { anaesthesia } \\
\text { (min) }\end{array}$} & \multicolumn{2}{|c|}{ Blood compensation*) } \\
\hline & & & $\begin{array}{l}\text { per- } \\
\text { operative } \\
\left(\mathrm{ml} \mathrm{kg} \mathrm{kg}^{-1}\right)\end{array}$ & $\begin{array}{l}\text { post- } \\
\text { operative } \\
\left(\mathrm{ml} \mathrm{kg}^{-1}\right)\end{array}$ \\
\hline 1 & 26 & 120 & 5.1 & 0 \\
\hline 2 & 60 & 140 & 0 & 0 \\
\hline 3 & 43 & 180 & 8.8 & 4.7 \\
\hline 4 & 115 & 120 & 0 & 0 \\
\hline 5 & 68 & 180 & 0 & 5.6 \\
\hline 6 & 30 & 210 & 0 & 9.3 \\
\hline 7 & 45 & 180 & 0 & 4.3 \\
\hline 8 & 62 & 300 & 24 & 5 \\
\hline 9 & 80 & 180 & 0 & 0 \\
\hline 10 & 96 & 210 & 0 & 0 \\
\hline 11 & 33 & 140 & 0 & 0 \\
\hline
\end{tabular}

*) S. table 1

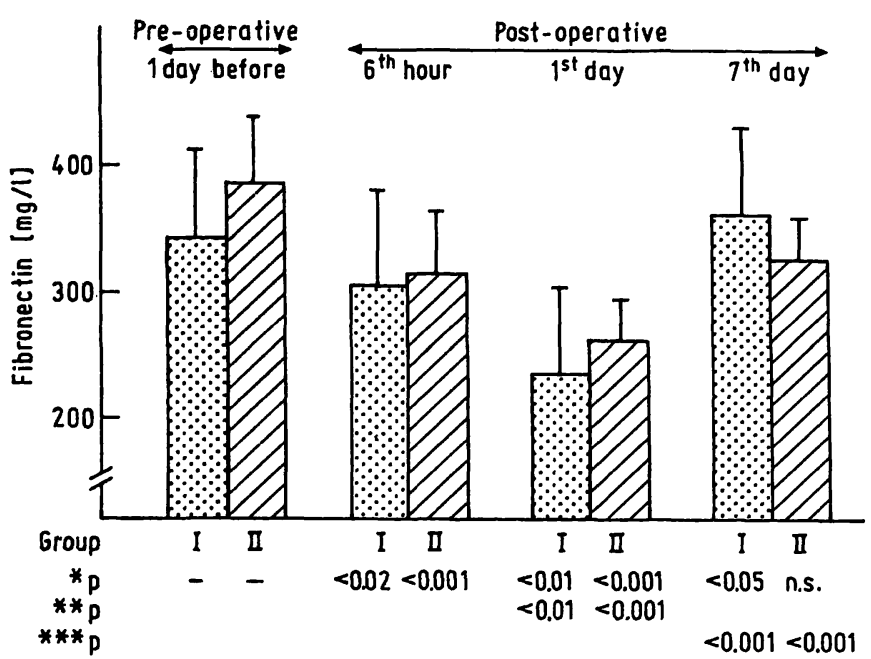

Fig. 1. Concentrations of fibronectin in plasma.

The data represent mean values with respective standard deviations.

*p: significant differences from the pre- and post-operative values

*** p: significant difference from post-operative $6^{\text {th }}$ hour and $1^{\text {st }}$ day

***p: significant differences from post-operative $1^{\text {st }}$ day and $7^{\text {th }}$ day.

\section{Discussion}

Pre-operative plasma fibronectin levels of our patients were similar to those already reported (1, 13). Since the pre-operative values of group I and group II did not differ in variance and mean, we were able to regroup the 21 patients into one group to determine if a correlation existed between the initial level of plasma fibronectin and age, as previously reported (13). In our group of 21 children there was no correlation $(r=0.08)$.

This disagreement with the results reported by Eriksen et al. (13) may be due to the fact that in their series, 23 children under 10 years of age were mixed with a population of 374 patients aged from a few months to 85 years. In fact, for the children under 15 years old, plasma fibronectin values furnished by Eriksen were approximately stable and identical to those which we found. Thus, our results should not be biased by age.

Among the children operated with cardio-pulmonary bypass we recorded a significant decline in plasma fibronectin concentration at the 6th post operative hour, continuing the following day (see fig. 1). By the 7 th post operative day the plasma fibronectin concentration had risen to a level somewhat lower than the initial pre-operative level. These results agree with those reported after aortocoronary bypass among adults (14). Of course, the decrease in plasma 
fibronectin concentration after cardio-pulmonary bypass could be attributed to an increased utilization or to dilution (14).

Increased utilization would occur if fibronectin were involved in the opsonization of microparticles put into circulation during cardio-pulmonary bypass (fragmented red corpuscles, diverse tissue fragments arising from recuperative aspirations, etc... or by fixation in the extracorporeal circuit, as previously reported after haemoperfusion in drug intoxicated patients (15). However, haemodialysis in chronic uraemic patients did not lower plasma fibronectin levels (16).

In children, the plasma fibronectin decline might be due to dilution owing to the relative importance of the cardio-pulmonary bypass circuit priming volume compared with the blood volume (see tab. 1). However, no relation between the percentage variation of plasma fibronectin and the volume of the cardiopulmonary bypass circuit $(r=-0.44)$ was found.

Transfusion with blood derivatives could be a perturbation factor, as patients operated with cardio-pulmonary bypass received an important volumetric compensation averaging two thirds to three fourths of their blood volume. This compensation was obtained with fresh frozen plasma and globular concentrates. We determined the plasma fibronectin concentration in 27 fresh frozen blood bank plasmas, immediately after thawing. The average concentration was $257 \pm$ $79 \mathrm{mg}^{-1}$. Thus, as the transfused plasma contained less fibronectin than that lost by the patients, an

\section{References}

1. Mosesson, M. W. \& Amarani, D. L. (1980) Blood 56, 145-158.

2. Pommier, C. G., Inada, S., Fries, L. F., Takahashi, T. Frank, M. M. \& Brown, E. J. (1983) J. Exp. Med. 157, 1844-1954.

3. Saba, T. M. (1970) Arch. Int. Med. 126, $1031-1052$.

4. Saba, T. M. \& Jaffe, E. (1980) Am. J. Med. 68, 577-594.

5. Kaplan, J. E. \& Saba, T. M. (1979) New-York, NY, 2, 83-92.

6. Lanser, M. E. \& Saba, T. M. (1982) Ann. Surg. 195, $340-345$.

7. Goodman, J. S., Schaffner, W., Collins, H. A., Battersby, E. G. \& Koening, M. G. (1968) New Engl. J. Med. 278, $117-123$.

8. Iribarren, C. O. I. \& Ekenstrom, S. (1964) J. Thorac. Cardiovasc. Surg. 47, 725-732.

9. Bor, D. H., Rose, R. M., Modlin, J. F., Weintraub, R. \& Griedland, G. M. (1983) Rev. Inf. Dis. 5, 885-897. effect of transfusion on the plasma fibronectin concentration would probably be dilutive. However there was no relation between the fall in plasma fibronectin and the volume of blood transfusions $(r=0.33)$. In addition, group II received an average volume compensation $\left(3.44 \pm 74 \mathrm{ml} \mathrm{kg}^{-1}\right)$ much less than that received by group I $\left(60.8 \pm 20.4 \mathrm{ml} \mathrm{kg}^{-1}\right)$. However, among group II children, the depletion of plasma fibronectin is comparable to that observed among the group I children, and the post-operative levels are not significantly different between the children operated with or without cardio-pulmonary bypass.

Thus, it does not appear that the utilisation of cardiopulmonary bypass (extra corporeal circuit with alien material, volume repletion dilution, heparinization, etc...) is in itself responsible for the post operative depletion of plasma fibronectin. It is probable that the surgical intervention in itself is capable of provoking this perturbation.

The absence of a significant difference between groups I and II may be due to the small sample size. However, if a large sample size had been employed it could at most demonstrate a minimal difference between group I and group II, as a significant difference would have been demonstrated even with a small population. Finally, even a minimal difference in plasma fibronectin would still be insufficient to explain the increased incidence of infection after cardio-pulmonary bypass surgery as compared to non cardio-pulmonary bypass surgery.

10. Parker, D. J., Contrell, J. W. \& Karp, R. B. (1972) Surgery $71,824-827$.

11. Silva, J. Jr., Hoeksema, H. \& Fekety, F. R. Jr. (1974) J. Thorac. Cardiovasc. Surg. 67, 175-183.

12. Mancini, G., Carbonara, A. O. \& Heremans, J. F. (1963) Immunochemistry 2, 235-254.

13. Eriksen, H. O., Clemmensen, I., Hansen, M.S. \& Ibsen, K. K. (1982) Scand. J. Clin. Lab. Invest. 42, 291-295.

14. Snyder, E. L., Barash, P. G., Mosher, D. F. \& Walter, S. D. (1983) J. Lab. Clin. Med. 102, $881-889$.

15. Lohmann, J., Pott, G., Voss, B. \& Gerlach, U. (1983) Klin. Wochenschr. 61, 369-372.

16. Eriksen, H. O., Tranebjaerg, L., Clemensen, I., Kjersem, H. \& Skjoldby, O. (1983) Scand. J. Clin. Lab. Invest. 43, $723-726$.

17. Freize, J., Muller, W. H. \& Hagerstedt, P. (1981) Res. Exp. Med. 178, 263-269.

Docteur F. Labrousse
Laboratoire de Biochimie
Hôpital Laennec
42, rue de Sèvres
F-75007 Pạris

Dopcteur F. Labrousse

Hôpital Laennec

F-75007 Pạis 